\title{
Molecular Identification of Gut Microflora of the Prawn Macrobrachium rosenbergii Fed with Probiotic Bacterium Bacillus licheniformis Supplemented Diet
}

A. Sudha, P. Saravana Bhavan", R. Udayasurian, T. Manjula, R. Kalpana and M. Karthik

Department of Zoology, Bharathiar University, Coimbatore - 641046, Tamil Nadu, India

DOI: $10.36348 /$ SJLS.2019.v04i09.004 $\quad$ | Received: 16.10 .2019 | Accepted: 22.10 .2019 | Published: 27.10 .2019

*Corresponding author: Dr. P. Saravana Bhavan

\section{Abstract}

Probiotics offer a wide range of health benefits to the host. The present paper deals with 16S r-RNA sequence analysis of gut microbial diversity of $M$. rosenbergii fed with $B$. licheniformis (MTCC 429; NCBI-GenBank accession number, MK158065 supplemented diet $\left(\mathrm{CFU}, 935 \times 10^{-6}\right)$. The $>10 \mathrm{~kb}$ genomic DNA yield $1500 \mathrm{pb}$ PCR amplified products against specific 16S r-RNA primers. The aligned sequences of the gut of control prawns showed $1337 \mathrm{bp}, 768 \mathrm{bp}, 1334$ bp, 1419 bp, 1315 bp, 1313 bp, 1466 bp and 1289 bp 16S r-RNA for Pseudomonas sp., Klebsiella oxytoca, Escherichia coli, Bacillus coagulans, Streptococcus thermophilus, Staphylococcus aureus, Citrobacter koseri and Acinetobacter sp., respectively. The gut of experimental prawns showed 1350 bp, 1495 bp, 1464 bp, 1307 bp, 1446 bp, and 1347 bp 16S r-RNA for Bacillus sp., Bacillus licheniformis, Lactobacillus plantarum, Escherichia coli, Streptococcus iniae and Citrobacter sp., respectively. The biochemical tests confirmed that the pathogenic bacteria, like Pseudomonas sp., Klebsiella sp., Staphylococcus sp., and Acinetobacter sp., have competitively been excluded from the gut of experimental prawns due to colony establishment of $B$. licheniformis and produced good growth [1]. The BLAST of these sequences showed almost $100 \%$ similarities with the same species retrieved from the NCBI database. The MAS showed 460 identical amino acids residues, 79 similar amino acids residues and 308 variable amino acids sites for control prawns, and 879 identical amino acids residues, 85 similar amino acids residues and 396 variable amino acids sites for experiment prawns. These sequences have less number of AT biases and more number of GC biases. Overall, the nucleotide divergence and the phylogenetic information calculated were clearly discriminated these bacterial species. Therefore, 16S r-RNA sequencing provides accurate identification of bacterial species. Thus, the phylogenetic tree topology showed very close/parallel alignment genera indentified from both control and experimental prawns.

Keywords: Prawn, Gut microflora, Probiotics, Bacillus licheniformis, 16S r-RNA.

Copyright @ 2019: This is an open-access article distributed under the terms of the Creative Commons Attribution license which permits unrestricted use, distribution, and reproduction in any medium for non-commercial use (NonCommercial, or CC-BY-NC) provided the original author and source are credited.

\section{INTRODUCTION}

Aquaculture has evolved as one of the fastest growing food production systems in the world, contributing significantly to global food security, and after finfish, a major share of the global aquaculture production is contributed by crustaceans [2]. The giant freshwater prawn, Macrobrachium rosenbergii (de Man 1879), is considered as a candidate species among crustaceans for aquaculture in different parts of tropical and subtropical belts and has economical importance due to its fast growth, high market demand and tolerance to environmental condition [3, 4]. Moreover, $M$. rosenbergii shows resistance to most of the viral diseases that have devastated marine shrimp farming [5].
The gut microbiota of an organism reflects its health status, and it is based on its surrounding environment [6-10]. However, the shift in microbial composition and structure is less affected by the surrounding environment, and the host itself is mainly shaped the stable gut microbial environment [11-14]. The intestinal microflora can help in converting the complex molecules into the simple one by their metabolic activities and serve as an important factor in nutrition, physiology and welfare of the host [15-17]. The available literature in related to gut microbiota of $M$. rosenbergii is moderate [18-22].Therefore studies are required to understand the probiotic relationship of any bacteria with host.

Probiotics are live microorganisms which when administered in adequate amounts confer a health 
benefit on the host [23]. Recent studies have shown that certain strains of Bacillus licheniformis confer significant probiotic actions and enhance the potential functional capacity of gut microbiota, promoting the growth and general immune response in human and animals $[24-27,1]$. B. licheniformis is a gram-positive, oxidase-positive and catalase-positive endospore forming non-pathogenic bacterium belonging to the genus Bacillus [28, 29]. It produces a wide range of extracellular enzymes [30, 31, 26]. It has been reported that $B$. licheniformis competitively excluded pathogenic bacteria from the gut with increased immune response in the white shrimp, Litopenaeus vannamei [32], in Penaeus japonicus [33] and in M. rosenbergii [1].

Mostly, Bacillus spp., are used as probiotic bacteria in aquaculture field, but accurate identification for these closely related species is difficult and laborious because conventional phenotypic tests fail to distinguish different strains. In addition, Bacillus spp., /strains have identical $16 \mathrm{~S}$ r-RNA gene sequences ( 99.2 - 99.6\% sequence similarity) [34, 35]. DNAbased identification methods like 16S r-RNA gene sequencing have been commonly/ widely used as a framework for identification, classification and quantification of microorganisms isolated from natural environments and gut samples [36, 37]. The $16 \mathrm{~S}$ r-RNA gene is a highly conserved component of the transcriptional machinery of all DNA-based life forms and thus is highly suited as a target gene for sequencing of different bacterial species for constructing their phylogenetic relationships [38, 39]. However, it often shows limited variation for members of closely related taxa [40, 41]. Recent taxonomic studies have indicated that $B$. licheniformis is closely related to $B$. subtilis and B. amyloliquefaciens according to comparisons of $16 \mathrm{~S}$ r-DNA and $16 \mathrm{~S}-23 \mathrm{~S}$ internal transcribed spacer (ITS) nucleotide sequences [42]. In general, 16S r-DNA sequences are used for Bacillus classification as a framework of species delineation [43]. Partial 16S r-DNA sequences near the 5' end region (approx $275 \mathrm{bp}$ ) have been useful parameters for the identification or grouping of Bacillus species [44]. $\mathrm{Xu} \&$ Cote [42] reported phylogenetic relationships between Bacillus and related genera based on sequence of a $220 \mathrm{bp}$ region covering the highly conserved 150 bp sequence at the 3' end of the 16S r-RNA coding region and the conserved $70 \mathrm{bp}$ sequence at $5^{\text {' end of }}$ 16-23S ITS region. A fast sensitive real time PCR assay for simultaneous detection of $B$. licheniformis, members of the B. cereus group and B. fumarioli in gelatin have been reported [45]. Moreover, it was accepted that species showing $70 \%$ or greater DNA homology usually have more than $97 \%$ 16S r-RNA gene sequence similarities [46].

Previously the prawn, $M$. rosenbergii post larvae were supplemented with five different serially diluted concentrations of $B$. licheniformis $\left(10^{-2}, 10^{-4}\right.$, $10^{-6}, 10^{-8}$ and $\left.10^{-10}\right)$. At $10^{-6}$ (CFU, 935 $\left.\times 10^{-6}\right)$, the presence of Pseudomonas sp., Klebsiella sp., E. coli., Bacillus sp., Streptococcus sp., Staphylococcus sp., Citrobacter sp., and Acinetobacter sp., were recorded in control prawns. In the experimental prawns, Bacillus sp., Lactobacillus sp., E. coli, Streptococcus sp., and Citrobacter sp., were observed. This revealed that the pathogenic bacteria, Pesudomonas sp., Klebsiella sp., Staphylococcus sp., and Acinetobacter sp., were found to have competitively been excluded from the gut of experimental prawns due to establishment of $B$. licheniformis colony, and produced good growth [1]. In the present paper the molecular identification of these bacterial species were done by analysing the DNA barcoding of $16 \mathrm{~S}$ rRNA.

\section{MATERIALS AND METHODS}

The probiotic bacterium, B. licheniformis was procured from Microbial Type Culture Collection (MTCC 429), Chandigarh, India, in lyophilized powder form. It was subjected to broth culture [1], sequenced and authenticated in NCBI-GenBank with the accession number, MK158065.

\section{DNA Barcoding of Gut Microbial Consortium of $M$. rosenbergii Fed with $B$. licheniformis Supplemented Diet}

\section{Isolation and Purification of Genomic DNA}

Bacterial genomic DNA was isolated from individual culture of Bacillus spp., (one colony), Lactobacillus spp., (three colonies), E. coli, Streptococcus spp., and Citrobacter spp., (one colony) by using phenol, chloroform, iso-amyl alcohol method (PCI) and they were homogenized in pre cooled mortar and pistol with 2 volume of cold TE buffer $(500 \mu \mathrm{l})$. Proteinase K $(20 \mu \mathrm{l})$ was added and incubated at $56^{\circ} \mathrm{C}$ for 1-8 hours until the tissue was totally dissolved. Equal volume of PCI was added with concentration of (25:24:1) and mixed thoroughly for few minutes. The sample was centrifuged for 10 minutes at $12,000 \mathrm{rpm}$. The upper phase was transferred to new $1.5 \mathrm{ml}$ tube, equal volume of Chloroform: Iso-amyl alcohol (24:1) was added and centrifuged at $12,000 \mathrm{rpm}$ for 10 minutes. The upper layer was transferred to a freshly sterilized micro centrifuge tube and double volume of child absolute ethanol was added. This preparation was kept at $-20^{\circ} \mathrm{C}$ over night for precipitation then centrifuged for 10 minutes at $10,000 \mathrm{rpm}$. The supernatant was discarded and $500 \mu \mathrm{l}$ of $70 \%$ ethanol was added. The sample was again centrifuged at 7,000 rpm for 10 minutes and the supernatant was removed. The pellet was kept for air dry under the laminar flow. The pellet was re-suspended in $100 \mu$ of nuclease free water or 1X TAE buffer [47].

To the sample $500 \mu 1$ of PCI was added and mixed slowly then it was incubated at $25^{\circ} \mathrm{C}$ for 5 minutes and centrifuged at $12,000 \mathrm{rpm}$ for 5 minutes at $4^{\circ} \mathrm{C}$. The aqueous phase was carefully removed into new centrifuge tube and treated two more times with PCI. The residual protein was eliminated from the 
aqueous phase by adding $400 \mu \mathrm{l}$ of chloroform, mixed slowly and centrifuged at $12,000 \mathrm{rpm}$ for 10 minutes at $4^{\circ} \mathrm{C}$. The upper aqueous phase was recovered and the DNA was precipitated by adding $10 \mu \mathrm{l}$ of $4 \mathrm{M}$ ammonium acetate and $500 \mu \mathrm{l}$ of cold absolute ethanol, then incubated at $-20^{\circ} \mathrm{C}$ for 20 minutes and centrifuged at $15,000 \mathrm{rpm}$ for 15 minutes at $4^{\circ} \mathrm{C}$. The precipitated DNA was cleaned with ethanol and the pellet was air dried. The pellet (containing Genomic DNA) was dissolved in $100 \mu \mathrm{l}$ of TE buffer and stored at $-20^{\circ} \mathrm{C}$ for future usage, or at $-80^{\circ} \mathrm{C}$ for long preservation.

\section{Agarose Gel Electrophoresis (AGE)}

Tank buffer, 1X TAE was prepared, (i. e, $365=350$ (tank capacity) $+15 \mathrm{ml}$ (boat capacity). The presence of genomic DNA was confirmed by $1 \%$ agarose gel. Agarose (150mg) was dissolved in $15 \mathrm{ml}$ of TAE buffer (the agarose was melted in TAE buffer under micro oven for 1 minute). A drop of ethidium bromide was added, casted at room temperature and poured into the boat. Then the comb was placed. After polymerization, the comb was carefully removed without damaging the wells. The boat was fixed into the tank filled with $350 \mathrm{ml}$ of $1 \mathrm{X}$ TAE buffer. The sample DNA was mixed with loading dye (containing Bromophenol blue and Glycerol in 2:6 ratio), and carefully loaded into the wells of the casted gel. The gel was given 100 volts DC for 30 minutes, safely removed and placed under UV transilluminator / GEL Documentation for viewing the DNA bands.

\section{Amplification of 16S r-RNA}

The 16S r-RNA gene was amplified in a Thermo Cycler (Applied Biosystem) by using these universal primers with forward and reverse in nature 5 'TGCCAGGCGGCCGCAGAGTRTGATCMTYGCTW AC-3, and 5'TGCCAGGCGGCCGCCGYTAMCTTWTTACGRCT$3^{\prime}$.

PCR was carried out with a final reaction volume of $50 \mu \mathrm{l}$ in $200 \mu \mathrm{l}$ capacity thin walled PCR tube. Composition of reaction mixture for PCR is given in Table-1. The PCR tubes containing the mixture were tapped gently and spined briefly at $10,000 \mathrm{rpm}$. The PCR tubes with all the components were transferred to thermal cycler. The condition for PCR is given in Table-2.

To confirm the targeted PCR amplification, $4 \mu \mathrm{l}$ of PCR product from each tube was mixed with $2 \mu \mathrm{l}$ of $6 \mathrm{X}$ gel loading dye. The $2 \%$ gel was constantly supplied with $50 \mathrm{~V} / \mathrm{cm}$ for $20 \mathrm{~min}$ in $1 \mathrm{X}$ TAE buffer. The amplified product (16S r-RNA) was visualized as a single compact band of expected size under UV light and documented by gel documentation system (Medicare, UK).

Table-1: Composition of reaction mixture for $\mathrm{PCR}$ with100 $\mu$ l reaction

\begin{tabular}{|l|c|}
\hline Components & Quantity \\
\hline DNA & $1 \mu \mathrm{l}(100 \mathrm{ng})$ \\
\hline Forward primer & $0.5 \mu \mathrm{l}(400 \mathrm{ng})$ \\
\hline Reverse primer & $0.5 \mu \mathrm{l}(400 \mathrm{ng})$ \\
\hline dNTPs (10 mM each) & $4 \mu \mathrm{l}$ \\
\hline 10X Chrom Taq RNA Polymerase Assay Buffer & $10 \mu \mathrm{l}$ \\
\hline Chrom Taq RNA Polymerase Enzyme $(3 \mathrm{U} / \mu \mathrm{l}) 1 \mu \mathrm{l}$ and Water & $84 \mu \mathrm{l}$ \\
\hline Total reaction volume: & $100 \mu \mathrm{l}$ \\
\hline
\end{tabular}

Source: Chromous Biotech Pvt. Ltd. Bengaluru, India (Manufacturer's protocol).

Table-2: Steps and conditions of thermal cycling for PCR

\begin{tabular}{|l|l|l|l|}
\hline Steps & Temperature(T) & Time & Cycles \\
\hline Initial Denaturation & $90^{\circ} \mathrm{C}$ & 5.00 min. & \\
\hline Final Denaturation & $90^{\circ} \mathrm{C}$ & 30 seconds & \multirow{2}{*}{35} \\
\hline Annealing & $50^{\circ} \mathrm{C}$ & 30 seconds & \multirow{2}{*}{35 . } \\
\cline { 1 - 3 } Extension & $72^{\circ} \mathrm{C}$ & 7.00 min. & \\
\cline { 1 - 3 } Final Extension & $72^{\circ} \mathrm{C}$ & \\
\hline
\end{tabular}

Source: Chromous Biotech Pvt. Ltd. Bengaluru, India (Manufacturer's protocol).

\section{Sequencing Reaction Preparations}

Sanger sequencing was adapted in which target RNA is denatured and annealed to an oligonucleotide primer, which is then extended by RNA polymerase using a mixture of deoxynucleotide triphosphates (normal dNTPs) and chain-terminating dideoxynucleotide triphosphates (ddNTPs). The ddNTPs lack the 3' OH group to which the next dNTP of the growing RNA chain is added. Without the $3^{\prime} \mathrm{OH}$, no more nucleotides can be added, and RNA polymerase falls off. The resulting newly synthesized RNA chains will be a mixture of lengths, depending on how long the chain was when a ddNTP was randomly incorporated.

\section{Template Quantity for PCR Product}

The following are the template quantity required to yield desired number of base pair sequences, 1-3ng/ $\mu \mathrm{l}$ (100-200bp), 3-10ng/ $\mu \mathrm{l}$ (200-500bp), 5-20ng/ 
$\mu \mathrm{l}$ (500-1000bp), 10-40ng/ $\mu \mathrm{l}$ (1000-2000bp), 25$50 \mathrm{ng} / \mu \mathrm{l}$ for single stranded plasmid, and $150-300 \mathrm{ng} / \mu \mathrm{l}$ for double stranded plasmid. In this study the desired number of base pairs was $1000-1500 \mathrm{bp}$, and therefore we used template volume of 5-20 $\mathrm{ng} / \mu \mathrm{l}$.

\section{Template Pre-Heat Treatment}

The template RNA was heated at $96^{\circ} \mathrm{C}$ for 5 minute in ABI Thermal Cycler and cooled in ice bath immediately and stored at $4^{\circ} \mathrm{C}$ until use. First PCR machine was switched and the program was set. Thawed the BDT $\vee 3.1$ kit on ice and aliquot $10 \mu \mathrm{l}$ of
RR mix into sterile $0.2 \mathrm{ml}$ microfuge tubes on ice and stored at $-20^{\circ} \mathrm{C}$. Sequencing reactions was prepared in $0.2 \mathrm{ml}$ PCR thin wall tube or micro plate well by placing the tube on ice. Addition was made in the order listed in the table below and the reagents was thawed and mixed thoroughly before use. The reaction content was mixed briefly in tube/plate, covered the plate with plate seal film and centrifuged for a quick spin of 20 seconds. The plates/tubes were transferred to the PCR machine and the PCR program was started as follows (Table 3 and 4).

Table-3: Template pre-heat treatment

\begin{tabular}{|l|l|l|}
\hline Reagent & Concentration & Volume \\
\hline Ready Reaction Premix & $2.5 \mathrm{X}$ & $4.0 \mu \mathrm{l}$ \\
\hline Big Dye Sequencing buffer & $5.0 \mathrm{X}$ & $2.0 \mu \mathrm{l}$ \\
\hline Primer & - & $3.2 \mathrm{pM} / \mu \mathrm{l}$ \\
\hline Template & - & $3.0 \mu \mathrm{l}$ \\
\hline Water & - & $10.0 \mu \mathrm{l}$ \\
\hline Final Volume & $1 \mathrm{X}$ & $20.0 \mu \mathrm{l}$ \\
\hline
\end{tabular}

Source: Chromous Biotech Pvt. Ltd. Bengaluru, India (Manufacturer's protocol).

Table-4: PCR sequencing cycling conditions

\begin{tabular}{|l|l|l|l|}
\hline Process & Temperature & Time & Cycles \\
\hline Initial Denaturation & $96^{\circ} \mathrm{C}$ & 1.0 seconds & 25 \\
\hline Denaturation & $96^{\circ} \mathrm{C}$ & 10.0 seconds & 25 \\
\hline Annealing & $50^{\circ} \mathrm{C}$ & 5.0 seconds & 25 \\
\hline Elongation & $60^{\circ} \mathrm{C}$ & 4.0 min. & -- \\
\hline
\end{tabular}

Source: Chromous Biotech Pvt. Ltd. Bengaluru, India (Manufacturer's protocol)

\section{Reactions Clean Up by Ethanolic Precipitation}

After completion of the PCR program, the sample was processed for ethanolic precipitation. From PCR tube, the samples were transferred to 96 well microlitre plates and $5 \mu \mathrm{l}$ of $125 \mathrm{mM}$ EDTA was added to each well. $60 \mu \mathrm{l}$ of ice cold $100 \%$ ethanol (from $20^{\circ} \mathrm{C}$ ) was added to each reaction, the plate was sealed and mixed by vortexing for 20-30 seconds and incubated at room temperature for 15 minutes. The sample plate was spun at $3,000 \times \mathrm{g}$ for 30 minutes at $4^{\circ} \mathrm{C}$. The supernatant was carefully removed by inverting the plate and spun up to $180 \times \mathrm{g}$, then removed from the centrifuge. The pellet was rinsed once with $60 \mu \mathrm{l}$ of ice cold $70 \%$ ethanol $\left(-20^{\circ} \mathrm{C}\right)$ by centrifugation at $1650 \times \mathrm{g}$ for 15 minutes at $4^{\circ} \mathrm{C}$. The plate was inverted and spun up to $180 \times \mathrm{g}$ for 1 minute, and then removed from the centrifuge. The sample was re-suspended in $10 \mu \mathrm{l}$ of $\mathrm{Hi}-\mathrm{Di}$ formamide and incubated for 15 minutes at room temperature. The resuspended samples were transferred to the appropriate wells of the sample plate. Ensured each sample was positioned at the bottom of its tube or well. The samples were denatured at $95^{\circ} \mathrm{C}$ for 5 minutes with snap chill and the plate was loaded into sequencer, and after completion, the data were analyzed.

\section{Bioinformatics Analysis (Sequence Annotations and Statistics)}

The sequence statistical analysis was conducted by various software's and online tools. The sequences were aligned with FASTA format, submitted to NCBI - GenBank database and authenticated. Before, the sequences were involved to found the nucleotide information, both forward and reverse sequences were merged (Contigs) with PRABI-Doua: CAP3 online tool. The sequences were subjected to basic local alignment search tool (BLAST) to find out the internal stop codon and reading frame shift. Finally, the starting codon was found for detecting the translated protein by using ORF finder. Ban kit sequence submission tool was used to submit the sequence to GenBank.

\section{Multiple Sequence Alignment}

Multiple sequence alignment (MSA) tool was used for aligning three or more biological sequences of similar length, generally protein, DNA, or RNA. From the output, sequence homology and evolutionary relationship between sequences was inferred.

\section{T- Coffee Alignment}

T-Coffee is a multiple sequence alignment package used to align sequences of protein, DNA and RNA or to combine the output of our favourite alignment methods (Clustal, Mafft, Probcons, Muscle, 
etc.) into one unique alignment (M-coffee). It can also able to combine sequence information with protein structural information (Expresso), profile information (PSI-Coffee) or RNA secondary structures (R-Coffee). This multiple sequence alignment web server has been introduced in 2011 NAR web server issue.

\section{Multiple Align Show (MAS)}

The Sequence Manipulation Suite is a collection of web-based programs for analyzing and formatting DNA and protein sequences. The output of each program is a set of HTML commands, which rendered by web browser as a standard web page.

The multiple align show (MAS) was used to highlight the amino acid residues in the sequences. The resulted sequences from $\mathrm{T}$-coffee were uploaded in MAS and the following parameters were selected: (i) identical amino acid residues in amino acid colour, (ii) similar amino acid residues in black colour, and, (iii) variable amino acids in white colour. After selecting these parameters, the sequences were submitted to NCBI-GenBank, and the subsequent data was appeared in new window.

\section{Phylogenetic Analysis}

Phylogenetic analysis is the process used to determine the evolutionary relationship between the organisms at the species level. The result of the analysis was drawn in a hierarchical diagram called 'Cladogram' or 'phylogram' (phylogenetic tree). The branch of the tree denotes the hypothesized evolutionary relationship (phylogeny). Each member in a branch, also known as a monophyletic group assumed to be descendants from a common ancestor. Originally, phylogenetic tree was created by morphological variations like sexual dimorphism, larvae/adult coloration of a given species, and now, it is carried out using DNA sequence.

\section{Synonymous and Non-Synonymous Substitution}

Estimation of synonymous (Ks) and nonsynonymous $(\mathrm{Ka})$ substitutions were calculated by Li93 method [48] of DAMBE for $3^{\text {rd }}$ codon position. The maximum likelihood (ML) analysis for the synonymous and non-synonymous substitutions was produced by joint reconstructions of ancestral states by Muse-Gaut model of codon substitution and Felsenstein model of nucleotide substitution [49].

\section{Saturation}

Analysis of sequence saturation was done by using DAMBE V 5.3.10 [50] for calculating the transitional and transvertional substitutions against genetic distance (TN93). The substantial saturation of the sequence was checked by using the method of [50, 51].
Molecular Evolutionary Genetics Analysis (MEGA V.6)

MEGA tool was used to find out the evolutionary relationship between the species using homologous sequences. It is based on the statistical analysis of genes, the percentages of conservedness, variance and parsimony of the sequences. The distance between groups was also estimated. The estimation was accomplished by bootstrapping approach. The information regarding transition and types of substitution between the sequences were used for inferring phylogenetics by distance based methods, along with bootstrap test. This tool was used for estimating evolutionary distance, constructing phylogenetic trees, testing tree reliability, making genes and domains, testing for selection, grouping, sequence computing and constructing tree from distance data. Sequences were aligned (Multiple align) using Bio Edit and the resulted sequences were converted in to MEGA format, which was used for reconstruction of phylogenetic tree topology.

\section{RESULTS AND DISCUSSION}

Molecular Characterization of Probiotic, $B$. licheniformis (MTCC 429) and Other Gut Bacteria of $M$. rosenbergii

The isolated genomic DNA from control prawn showed greater than $10 \mathrm{~kb}$ size (Figure-1) and the PCR amplified DNA for 16S rRNA gene showed $1500 \mathrm{bp}$ (Figure-3). Actually the aligned sequence showed 1516 bp for B. licheniformis sub-culture (MTCC 429; NCBI-GenBank accession number, MK158065 which showed $100 \%$ similarity with the colony of B. licheniformis (1495 bp; MK955479) that was established in the gut of $M$. rosenbergii, and further showed $99 \%$ similarity with the same species which existed in NCBI database. The aligned sequences from the gut of control showed 1337 bp for Pseudomonas sp., 768 bp for Klebsiella oxytoca, 1334 bp for Escherichia coli, 1419 bp for Bacillus coagulans, 1315 bp for Streptococcus thermophilus, 1313 bp for Staphylococcus aureus, 1466 bp for Citrobacter koseri and 1289 bp for Acinetobacter sp., The details of BLAST for these sequences, the similarity data $(99.9-100 \%)$ retrieved from the NCBI database and the GenBank accession numbers are presented in Table- 5 .

The isolated genomic DNA from experimental prawn also showed greater than $10 \mathrm{~kb}$ size (Figure-2) and the PCR amplified DNA for 16S rRNA gene also showed $1500 \mathrm{bp}$ (Figure-4). Here, the aligned sequence showed 1350 bp for Bacillus sp., 1495 bp for Bacillus licheniformis, 1464 bp for Lactobacillus plantarum, 1307 bp for Escherichia coli, 1446 bp for Streptococcus iniae and $1347 \mathrm{bp}$ for Citrobacter sp. The details of BLAST for these sequences, the similarity data (100\%) retrieved from the NCBI database and the GenBank accession numbers are presented in Table- 6 . 


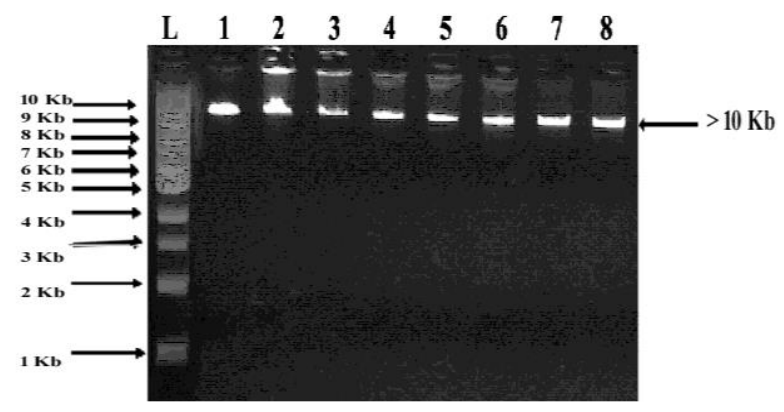

Fig-1: AGE (1\%) shows >10 kb genomic DNA for bacterial colonies established in the gut of control prawns. L. Ladder (1kb); 1. Pseudomonas sp.;

2. Klebsiella oxytoca; 3. Escherichia coli; 4. Bacillus coagulans; 5. Streptococcus thermophilus; 6. Staphylococcus aureus; 7. Citrobacter koseri; 8. Acinetobacter sp., Source: Paper authors original work.

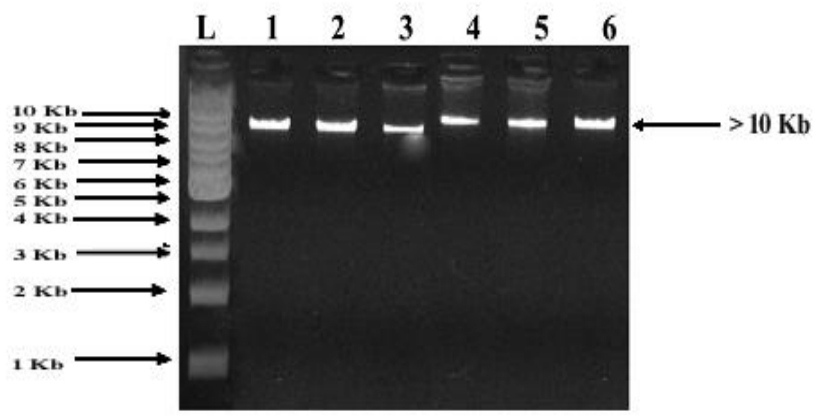

Fig-2: AGE (1\%) shows >10 kb genomic DNA for bacterial colonies established in the gut of experimental prawns. L. Ladder (1kb); 1. Bacillus sp.; 2. Bacillus licheniformis; 3. Lactobacillus plantarum; 4. Escherichia coli; 5. Streptococcus iniae; 6. Citrobacter sp., Source: Paper authors original work

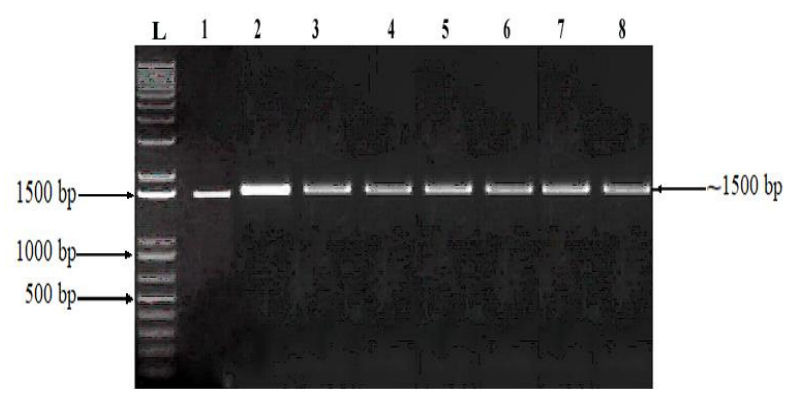

Fig-3: AGE (2\%) shows $\sim 1500$ bp of amplified product of 16S rRNA of bacterial colonies established in the gut of control prawns. L. Ladder (100 bp); 1. Pseudomonas sp.,; 2. Klebsiella oxytoca; 3. Escherichia coli; 4. Bacillus coagulans; 5. Streptococcus thermophilus; 6. Staphylococcus aureus; 7. Citrobacter koseri; 8. Acinetobacter sp.,

Source: Paper authors original work.

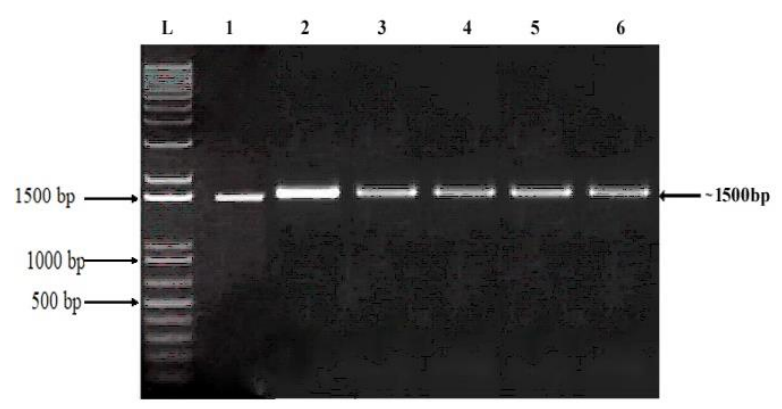

Fig-4: AGE (2\%) shows 1500 bp of amplified product of 16S rRNA of bacterial colonies established in the gut of experimental prawns. L. Ladder (100 bp); 1. Bacillus sp.; 2. Bacillus licheniformis; 3. Lactobacillus plantarum; 4. Escherichia coli; 5. Streptococcus iniae; 6. Citrobacter sp., Source: Paper authors original work. 
Table-5: BLAST identification of 16S rRNA gene sequences of control, and retrieved bacterial species

\begin{tabular}{|c|c|c|c|c|c|c|}
\hline $\begin{array}{l}\text { Queried } \\
\text { Sequences }\end{array}$ & $\begin{array}{l}\text { Author, Country and } \\
\text { Accession Number }\end{array}$ & $\begin{array}{l}\text { I } \\
(\%)\end{array}$ & $\begin{array}{l}\mathbf{G} \\
(\%)\end{array}$ & M.S & $\begin{array}{l}\text { Retrieved/ Matched } \\
\text { species }\end{array}$ & $\begin{array}{l}\text { Author, Country and } \\
\text { Accession Number }\end{array}$ \\
\hline $\begin{array}{l}\text { Pseudomonas sp., } \\
\text { (1337 bp) }\end{array}$ & $\begin{array}{l}\text { Paper authors, } \\
\text { India } \\
\text { MK955470 }\end{array}$ & 100 & 0 & Plus & Pseudomonas sp., & $\begin{array}{l}\mathrm{He}, 2017 \\
\text { China } \\
\text { KY927414.1 }\end{array}$ \\
\hline $\begin{array}{l}\text { Klebsiella oxytoca } \\
\text { (768 bp) }\end{array}$ & $\begin{array}{l}\text { Paper authors, } \\
\text { India } \\
\text { MK955471 }\end{array}$ & 100 & 0 & Plus & Klebsiella oxytoca & $\begin{array}{l}\text { Jaddo, et al., } 2018 \\
\text { (Iraq) } \\
\text { MH295829.1 }\end{array}$ \\
\hline $\begin{array}{l}\text { Escherichia coli } \\
\text { (1334 bp) }\end{array}$ & $\begin{array}{l}\text { Paper authors, } \\
\text { India } \\
\text { MK955472 }\end{array}$ & 100 & 0 & Plus & Escherichia coli & $\begin{array}{l}\text { Pulgar, et al., } 2015 \\
\text { Chille } \\
\text { KU204888.1 }\end{array}$ \\
\hline $\begin{array}{l}\text { Bacillus coagulans } \\
(1419 \mathrm{bp})\end{array}$ & $\begin{array}{l}\text { Paper authors, } \\
\text { India } \\
\text { MK955473 }\end{array}$ & 100 & 0 & Plus & Bacillus coagulans & $\begin{array}{l}\text { Tanaka, et al., } 2007 \\
\text { Japan } \\
\text { Ab362709.1 }\end{array}$ \\
\hline $\begin{array}{l}\text { Streptococcus } \\
\text { thermophilus } \\
(1316 \mathrm{bp})\end{array}$ & $\begin{array}{l}\text { Paper authors, } \\
\text { India } \\
\text { MK955474 } \\
\end{array}$ & 99.92 & 0 & Plus & $\begin{array}{l}\text { Streptococcus } \\
\text { thermophilus }\end{array}$ & $\begin{array}{l}\text { Mo, et al., } 2018 \\
\text { Switerland } \\
\text { Mg755342.1 } \\
\end{array}$ \\
\hline $\begin{array}{l}\text { Staphylococcus } \\
\text { aureus } \\
(1313 \mathrm{bp})\end{array}$ & $\begin{array}{l}\text { Paper authors, } \\
\text { India } \\
\text { MK955475 }\end{array}$ & 100 & 0 & Plus & Staphylococcus aureus & $\begin{array}{l}\text { Buszewski, et al., } 2019 \\
\text { Poland } \\
\text { MK681353.1 }\end{array}$ \\
\hline $\begin{array}{l}\text { Citrobacter koseri } \\
(1466 \mathrm{bp})\end{array}$ & $\begin{array}{l}\text { Paper authors, } \\
\text { India } \\
\text { MK955476 }\end{array}$ & 100 & 0 & Plus & Citrobacter koseri & $\begin{array}{l}\text { Cairns } 2017 \\
\text { Finland } \\
\text { LT899939.1 }\end{array}$ \\
\hline $\begin{array}{l}\text { Acinetobacter sp., } \\
(1289 \mathrm{bp})\end{array}$ & $\begin{array}{l}\text { Paper authors, } \\
\text { India } \\
\text { MK955477 }\end{array}$ & 100 & 0 & Plus & Acinetobacter sp., & $\begin{array}{lll}\text { Boivin-Jahns, et al., } & \text { el } \\
1995 & & \\
\text { France } & & \\
\text { X86572.1 } & & \\
\end{array}$ \\
\hline
\end{tabular}

I: Identity; G: Gap; M.S: Matched strand

Table-6: BLAST identification of 16r RNA gene sequences for experimental group and retrieved bacteria species and their GenBank accession numbers

\begin{tabular}{|c|c|c|c|c|c|c|}
\hline $\begin{array}{l}\text { Queried } \\
\text { sequences }\end{array}$ & $\begin{array}{l}\text { Author, Country and } \\
\text { Accession Number }\end{array}$ & $\begin{array}{l} \\
(\%)\end{array}$ & $\begin{array}{l}\mathbf{G} \\
(\%)\end{array}$ & M.S & $\begin{array}{l}\text { Retrieved/ Matched } \\
\text { species }\end{array}$ & $\begin{array}{l}\text { Author, Country and } \\
\text { Accession Number }\end{array}$ \\
\hline $\begin{array}{l}\text { Bacillus sp., } \\
\text { (1350 bp) }\end{array}$ & $\begin{array}{l}\text { Paper authors, } \\
\text { India } \\
\text { MK955478 }\end{array}$ & 100 & 0 & Plus & Bacillus sp & $\begin{array}{l}\text { Lu, } 2017 \\
\text { China } \\
\text { MG309335.1 }\end{array}$ \\
\hline $\begin{array}{l}\text { Bacillus } \\
\text { licheniformis } \\
(1495 \mathrm{bp})\end{array}$ & $\begin{array}{l}\text { Paper authors, } \\
\text { India } \\
\text { MK955479 }\end{array}$ & 100 & 0 & Plus & $\begin{array}{l}\text { Bacillus } \\
\text { licheniformis }\end{array}$ & $\begin{array}{l}\text { Aboelnaga, et al., } 2018 \\
\text { Egypth } \\
\text { MK028349.1 }\end{array}$ \\
\hline $\begin{array}{l}\text { Lactobacillus } \\
\text { plantarum } \\
(1464 \mathrm{bp})\end{array}$ & $\begin{array}{l}\text { Paper authors, } \\
\text { India } \\
\text { MK955480 }\end{array}$ & 100 & 0 & Plus & $\begin{array}{l}\text { Lactobacillus } \\
\text { plantarum }\end{array}$ & $\begin{array}{l}\text { Zhang, } 2018 \\
\text { China } \\
\text { MH016559.1 }\end{array}$ \\
\hline $\begin{array}{l}\text { Escherichia coli } \\
\text { (1307 bp) }\end{array}$ & $\begin{array}{l}\text { Paper authors, } \\
\text { India } \\
\text { MN121246 }\end{array}$ & 100 & 0 & Plus & Escherichia coli & $\begin{array}{l}\text { Mandakovic, et al., } 2015 \\
\text { Chile } \\
\text { KU204888.1 }\end{array}$ \\
\hline $\begin{array}{l}\text { Streptococcus } \\
\text { iniae } \\
\text { (1446 bp) }\end{array}$ & $\begin{array}{l}\text { Paper authors, } \\
\text { India } \\
\text { MN121247 }\end{array}$ & 100 & 0 & Plus & Streptococcus iniae & $\begin{array}{l}\text { Hoshino, et al., } 2008 \\
\text { Japan } \\
\text { AB470235.1 }\end{array}$ \\
\hline $\begin{array}{l}\text { Citrobacter sp., } \\
\text { (1347 bp) }\end{array}$ & $\begin{array}{l}\text { Paper authors, } \\
\text { India } \\
\text { MN121248 }\end{array}$ & 100 & 0 & Plus & Citrobacter sp., & $\begin{array}{l}\text { Haque, et al., } 2019 \\
\text { Bangladesh } \\
\text { MK695712.1 }\end{array}$ \\
\hline
\end{tabular}

I: Identity; G: Gap; M.S: Matched strand

The MAS showed 460 identical amino acid residues, 79 similar amino acid residues and 308 variable amino acid sites for control prawns (Figure-7), and 879 identical amino acid residues, 85 similar amino acid residues and 396 variable amino acid sites for experiment prawns, which are presented in Figure-8.

The Sequence Manipulation Suite: Multiple Align Show 


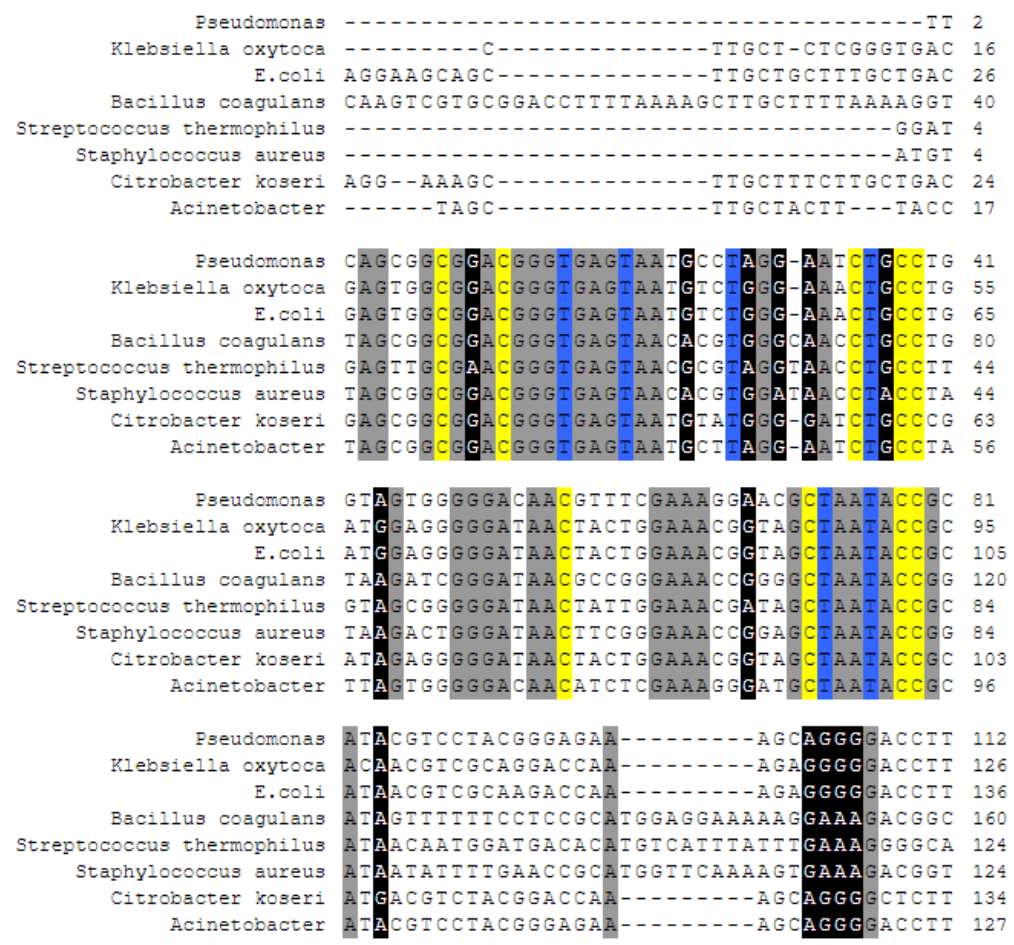

Fig-7: Multiple sequence alignment of 16S r-RNA gene sequences of bacterial species identified in the gut M. rosenbergii PL fed with control diet. Multiple align show (MAS) with coloured background (identical residues are indicated by amino acid colour and similar residues are black in colour. Gaps and other residues are given in white background)

The Sequence Manipulation Suite: Multiple Align Show

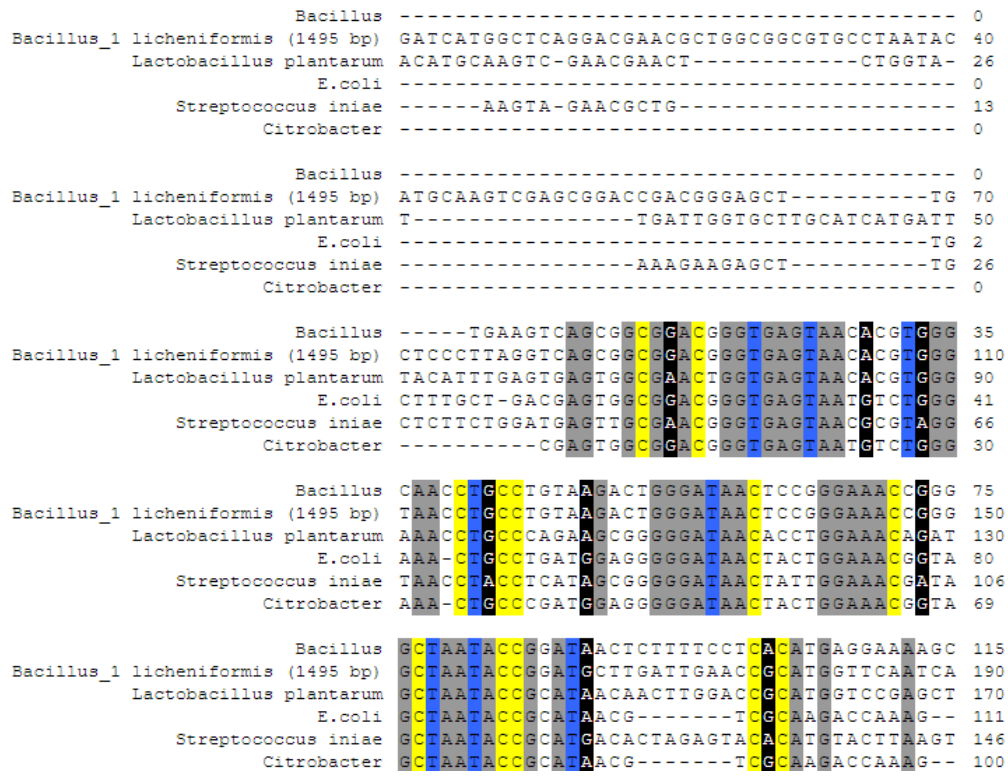

Fig-8: Multiple sequence alignment of 16S r-RNA gene sequences of bacterial species identified in the gut of $M$. rosenbergii PL fed with $B$. licheniformis incorporated diet. Multiple align show (MAS) with coloured background (identical residues are indicated by amino acid colour and similar residues are black in colour. Gaps and other residues are given in white background)

The nucleotide composition showed more GC biases, 50.6-56.4\% (Staphylococcus aureus and Bacillus coagulans) and less AT biases, 43.6-49.4\% (Bacillus coagulans and Staphylococcus aureus) in the control prawns (Table-7). In the experimental prawns as well there were more GC biases, 51.2-55.7\% (Lactobacillus plantarum and Bacillus licheniformis) and less AT biases, 44.3-48.8\% (Bacillus licheniformis and Lactobacillus plantarum) (Table-8). The lower AT biases recorded in control and experimental prawns indicate the less abundance of nuclear copies of mtDNA (NUMTs) known as pseudogenes, homologs or paralogs. 
Table-7: 16S r-RNA nucleotide composition of bacterial species identified in the gut of $M$. rosenbergii PL fed with control diet

\begin{tabular}{|l|l|l|l|l|l|l|l|}
\hline Prawn category & Bacterial Species & A & T & AT & C & G & GC \\
\hline \multirow{3}{*}{$\begin{array}{l}\text { M. rosenbergii PL } \\
\text { fed with }\end{array}$} & Pseudomonas sp., & 25.5 & 20.8 & 46.3 & 22.5 & 31.2 & 53.7 \\
\cline { 2 - 7 } & Klebsiella oxytoca & 24.1 & 20.4 & 44.5 & 22.9 & 32.6 & 55.5 \\
\cline { 2 - 7 } & Escherichia coli & 24.7 & 20.0 & 44.8 & 23.3 & 31.9 & 55.2 \\
\cline { 2 - 7 } & Bacillus coagulans & 24.4 & 19.2 & 43.6 & 24.8 & 31.6 & 56.4 \\
\cline { 2 - 7 } & Streptococcus thermophilus & 25.5 & 22.1 & 47.5 & 22.0 & 30.5 & 52.5 \\
\cline { 2 - 7 } & Staphylococcus aureus & 27.3 & 22.1 & 49.4 & 21.7 & 28.9 & 50.6 \\
\cline { 2 - 7 } & Citrobacter koseri & 25.9 & 20.9 & 46.8 & 21.8 & 31.4 & 53.2 \\
\cline { 2 - 7 } & Acinetobacter sp., & 25.8 & 21.7 & 47.6 & 21.6 & 30.9 & 52.4 \\
\hline Average & $\mathbf{2 5 . 4}$ & $\mathbf{2 0 . 9}$ & $\mathbf{4 6 . 3}$ & $\mathbf{2 2 . 5}$ & $\mathbf{3 1 . 1}$ & $\mathbf{5 3 . 6}$ \\
\hline
\end{tabular}

Source: Paper authors original work

Table-8: 16S r-RNA nucleotide composition of bacterial species identified in the gut of $M$. rosenbergii PL fed with B. licheniformis incorporated diet

\begin{tabular}{|l|l|l|l|l|l|l|l|}
\hline Prawn category & Bacterial Species & A & T & AT & C & G & GC \\
\hline \multirow{2}{*}{$\begin{array}{l}\text { M. rosenbergii PL } \\
\text { fed with }\end{array}$} & Bacillus sp., & 25.3 & 19.6 & 44.9 & 24.2 & 30.9 & 55.1 \\
\cline { 2 - 8 } $\begin{array}{l}\text { B. licheniformis } \\
\text { incorporated diet }\end{array}$ & Bacillus licheniformis & 24.5 & 19.8 & 44.3 & 24.1 & 31.5 & 55.7 \\
\cline { 2 - 8 } & Lactobacillus plantarum & 26.5 & 22.3 & 48.8 & 21.9 & 29.4 & 51.2 \\
\cline { 2 - 8 } & Escherichia coli & 24.7 & 20.2 & 44.9 & 23.0 & 32.1 & 55.1 \\
\cline { 2 - 8 } & Streptococcus iniae & 26.5 & 21.8 & 48.3 & 21.8 & 29.9 & 51.7 \\
\cline { 2 - 8 } & Citrobacter sp., & 25.4 & 19.8 & 45.2 & 22.9 & 31.8 & 54.8 \\
\hline Average & $\mathbf{2 5 . 5}$ & $\mathbf{2 0 . 6}$ & $\mathbf{4 6 . 1}$ & $\mathbf{2 3 . 0}$ & $\mathbf{3 0 . 9}$ & $\mathbf{5 3 . 9}$ \\
\hline
\end{tabular}

Source: Paper authors original work.

The inter species divergence of control prawns was lower (0.059) between Klebsiella oxytoca vs. Escherichia coli and higher (0.366) between Streptococcus thermophilus vs. Acinetobacter sp., (Table-9). The inter species divergence of experiment prawns was lower (0.032) Citrobacter sp., vs. Escherichia coli and high (0.345) between Citrobacter sp., vs. Streptococcus iniae (Table-10). These results indicated very close relationship between the species.

Table-9: 16S r-RNA nucleotide divergence of bacterial species identified in the gut of control prawns

\begin{tabular}{|c|c|}
\hline Between Species & Divergence (\%) \\
\hline Pseudomonas sp., vs. Klebsiella oxytoca & 0.206 \\
\hline Pseudomonas sp., vs. Escherichia coli & 0.174 \\
\hline Klebsiella oxytoca vs. Escherichia coli & 0.059 \\
\hline Pseudomonas sp., vs. Bacillus coagulans & 0.310 \\
\hline Klebsiella oxytoca vs. Bacillus coagulans & 0.335 \\
\hline Escherichia coli vs. Bacillus coagulans & 0.306 \\
\hline Pseudomonas sp., vs. Streptococcus thermophilus & 0.299 \\
\hline Klebsiella oxytoca vs. Streptococcus thermophilus & 0.358 \\
\hline Escherichia coli vs. Streptococcus thermophilus & 0.320 \\
\hline Bacillus coagulans vs. Streptococcus thermophilus & 0.205 \\
\hline Pseudomonas sp., vs. Staphylococcus aureus & 0.303 \\
\hline Klebsiella oxytoca vs. Staphylococcus aureus & 0.360 \\
\hline Escherichia coli vs. Staphylococcus aureus & 0.323 \\
\hline Bacillus coagulans vs. Staphylococcus aureus & 0.120 \\
\hline Streptococcus thermophilus vs. Staphylococcus aureus & 0.191 \\
\hline Pseudomonas sp., vs. Citrobacter koseri & 0.187 \\
\hline Klebsiella oxytoca vs. Citrobacter koseri & 0.112 \\
\hline Escherichia coli vs. Citrobacter koseri & 0.083 \\
\hline Bacillus coagulans vs. Citrobacter koseri & 0.315 \\
\hline Streptococcus thermophilus vs. Citrobacter koseri & 0.342 \\
\hline Staphylococcus aureus vs. Citrobacter koseri & 0.337 \\
\hline Pseudomonas sp., vs. Acinetobacter sp., & 0.144 \\
\hline Klebsiella oxytoca vs. Acinetobacter sp., & 0.227 \\
\hline Escherichia coli vs. Acinetobacter sp., & 0.197 \\
\hline Bacillus coagulans vs. Acinetobacter sp., & 0.317 \\
\hline Streptococcus thermophilus vs. Acinetobacter sp., & 0.366 \\
\hline Staphylococcus aureus vs. Acinetobacter $\mathrm{sp}$. & 0.342 \\
\hline Citrobacter koseri vs. Acinetobacter sp., & 0.162 \\
\hline
\end{tabular}


Table-10: 16S r-RNA nucleotide divergences of bacterial species identified in the gut of $M$. rosenbergii PL fed with B. licheniformis incorporated diet

\begin{tabular}{|l|l|}
\hline Between Species & Divergence (\%) \\
\hline Bacillus licheniformis vs. Bacillus sp., & 0.044 \\
\hline Bacillus licheniformis vs. Citrobacter sp., & 0.334 \\
\hline Bacillus sp., vs. Citrobacter sp & 0.319 \\
\hline Bacillus licheniformis vs. Escherichia coli & 0.327 \\
\hline Bacillus sp., vs. Escherichia coli & 0.315 \\
\hline Citrobacter sp., vs. Escherichia coli & 0.032 \\
\hline Bacillus licheniformis vs. Lactobacillus plantarum & 0.150 \\
\hline Bacillus sp., vs. Lactobacillus plantarum & 0.138 \\
\hline Citrobacter sp., vs. Lactobacillus plantarum & 0.334 \\
\hline Escherichia coli vs. Lactobacillus plantarum & 0.339 \\
\hline Bacillus licheniformis vs. Streptococcus iniae & 0.177 \\
\hline Bacillus sp., vs. Streptococcus iniae & 0.165 \\
\hline Citrobacter sp., vs. Streptococcus iniae & 0.345 \\
\hline Escherichia coli vs. Streptococcus iniae & 0.336 \\
\hline Lactobacillus plantarum vs. Streptococcus iniae & 0.183 \\
\hline
\end{tabular}

\section{Phylogenetic Relationship of Gut Bacterial} Consortium of $M$. rosenbergii

In the control prawns, the non-synonymous (Ka) substitution was higher (2.413) than that of synonymous (Ks) substitution (0.751), which indicates the possibility of occurrence of more deleterious mutation and less silent mutation. Similarly, the transversional (Tv) substitution was higher (0.16) than that of transitional (Ts) (0.13), which indicates the fact that these sequences have more phylogenetic information. However, saturation had not occurred in these sequences, which was confirmed by the predicted higher critical value of index of substitutional saturation (Iss.c), 0.716 than that of index of substitution saturation (Iss), 0.338, and therefore more phylogenetic differences existed between sequences (Table 11; Figure 9). The same trend was observed in the experimental prawns as well $(\mathrm{Ka}=0.879, \mathrm{Ks}=2.457$, $\mathrm{Tv}=0.35, \mathrm{Ts}=0.25$ Iss.c $=0.889$, Iss $=0.448)($ Table$11 \&$ Figure-10).

Table-11: Phylogenetic information of bacterial species identified (based on 16S r-RNA) in the gut of $M$. rosenbergii PL fed with $B$. licheniformis incorporated diet

\begin{tabular}{|l|l|l|l|l|l|l|l|l|l|}
\hline Phylogenetic information & Ks & Ka & Ka-Ks & Ts & Tv & Tv-Ts & Iss & Iss.c & Iss.c - Iss \\
\hline Control & 0.751 & 2.413 & 1.662 & 0.13 & 0.16 & 0.03 & 0.338 & 0.716 & 0.378 \\
\hline Experimental & 0.879 & 2.457 & 1.578 & 0.25 & 0.35 & 0.1 & 0.448 & 0.889 & 0.441 \\
\hline
\end{tabular}

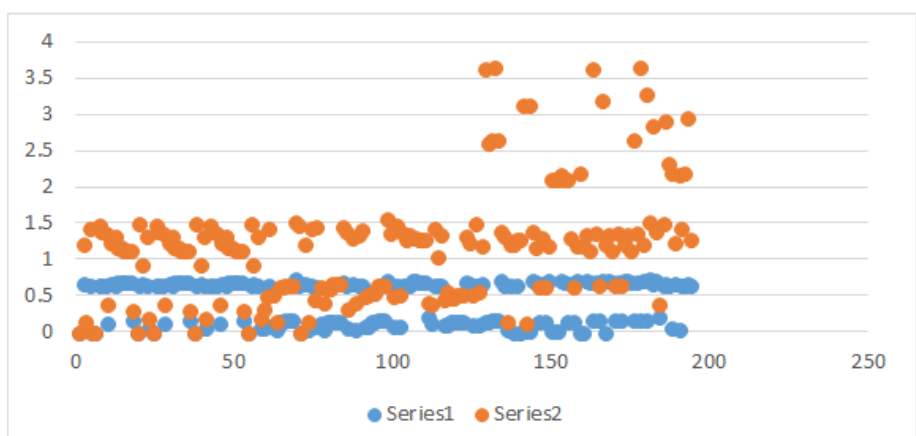

A. Number of synonymous (Ks) and non-synonymous (Ka) substitutions occurred at $3^{\text {rd }}$ codon position in the nucleotides of $16 \mathrm{~S} \mathrm{r}$ RNA gene partial sequences of control prawns 


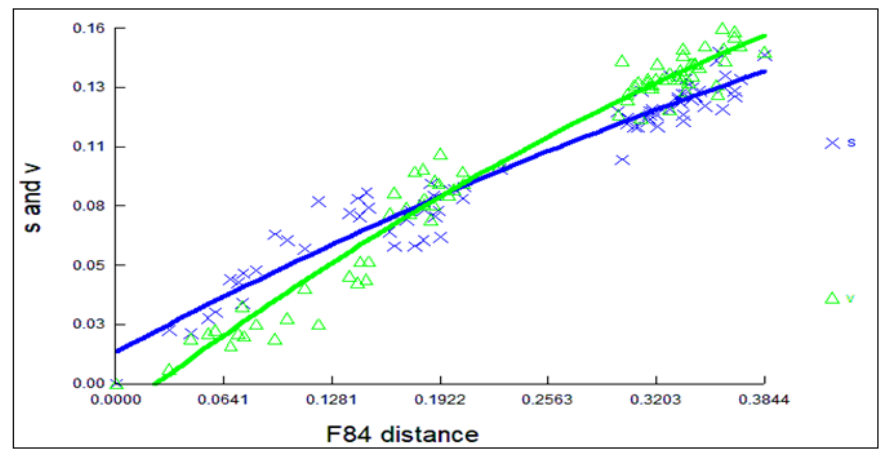

B. Scattergram of transitional (X, blue) and transversional ( $\Delta$, green) type substitutions occurred in 16S r-RNA gene partial sequences of bacterial diversity identified in the gut of control prawns

Fig-9: Synonymous (Ks) and non-synonymous $(\mathrm{Ka})$, transitional $(\mathrm{X}$, blue) and transversional ( $\Delta$, green) substitutions occurred in16S r-RNA partial gene sequences for control prawns

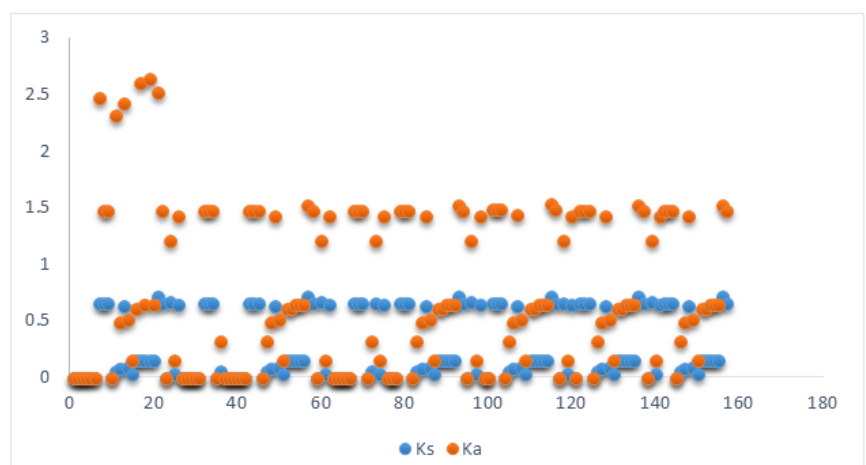

A. Number of synonymous (Ks) and non-synonymous (Ka) substitutions occurred at $3^{\text {rd }}$ codon position in the nucleotides of $16 \mathrm{~S}$ rRNA gene partial sequences of experimental prawns

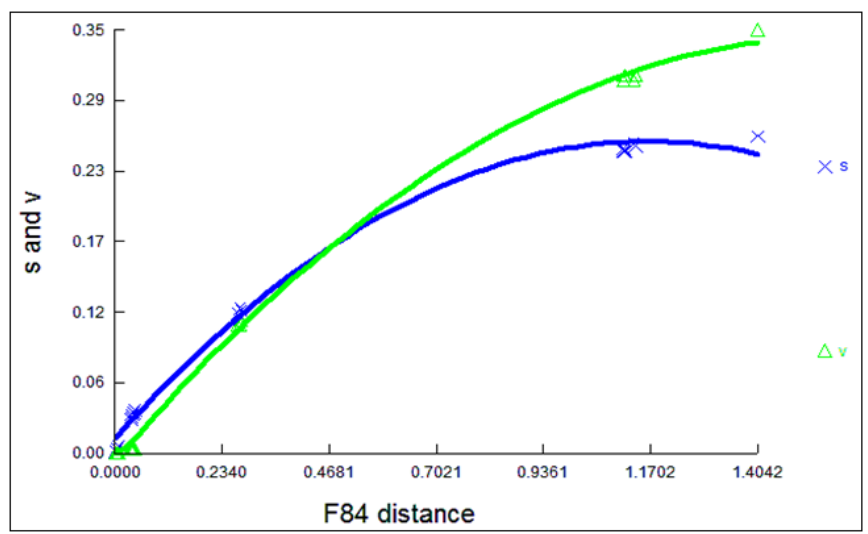

B. Scattergram of transitional (X, blue) and transversional ( $\Delta$, green) type substitutions occurred in 16S r-RNA gene partial sequences of bacterial diversity identified in the gut of $M$. rosenbergii PL fed with $B$. lichiformis incorporated diet

Fig-10: Synonymous (Ks) and non-synonymous (Ka), transitional (X, blue) and transversional ( $\Delta$, green) substitutions occurred in16S r-RNA partial gene sequences for experimental prawns

The phylogenetic tree topology of bacterial species identified in the gut of control prawns shows three clusters. The first cluster was formed by $S$. aureus and $B$. coagulans as sister taxa with bootstrap value of 100 , and $S$. thermophilus was sat alone. The second cluster was formed by Acinetobacter sp., and
Pseudomonas sp., as sister taxa with bootstrap value of 57. The third cluster was formed by $C$. koseri as a lone clade, and $E$. coli and $K$. oxytoca were aligned as sister taxa at the top of the tree with bootstrap value of 100 (Figure-11). 


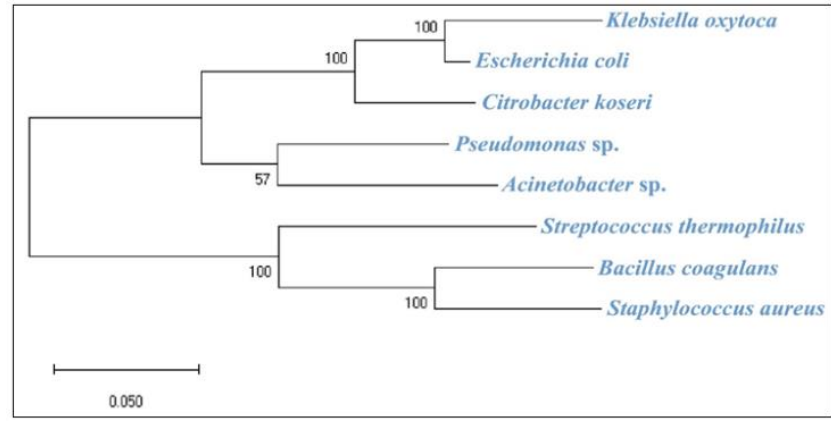

Fig-11: 16S r-RNA based phylogenetic tree topology of bacterial species identified in the gut of control prawns

The phylogenetic tree for the experimental prawns shows two major clusters. The first cluster at bottom of the tree was with Citrobacter sp., and E. coli aligned as a sister taxa with bootstrap value of 100 . The second major cluster includes 2 clades and a cluster, $S$. iniae and L. plantarum were separately aligned as distinct clades, and B. licheniformis and Bacillus sp., were aligned as a sister taxa with bootstrap value of 100 (Figure-12).

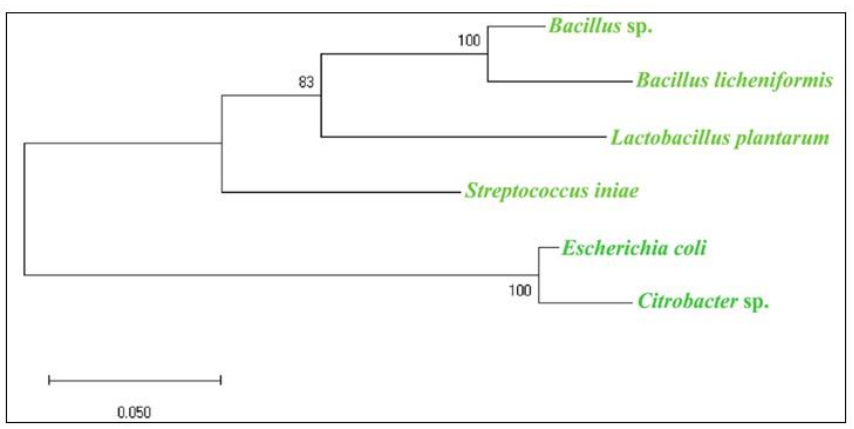

Fig-12: 16S r-RNA based phylogenetic tree topology of bacterial species identified in the gut of M. rosenbergii PL fed with B. licheniformis incorporated diet

When the bacterial species identified in the gut of both control and experimental prawns were pooled together, the phylogenetic tree topology appears with two major clusters, each of which was with five clades. In the first cluster, the identified Bacillus sp. aligned at the bottom of the tree as a sister clade with B. coagulan. The remaining species, such as $B$. licheniformis, $S$. aureus and L. plantarum were aligned in three separate clades. $S$. inae of experimental prawns and $S$. thermophiles of control prawns aligned as a sister taxa at the top of the first cluster (Figure-13).
The second cluster, there were three separate clades with Pseudomonas sp., Acinetobacter sp., and $C$. koseri, respectively. There were two sister taxa, first with $E$. coli of control and experimental prawns, and second sister taxa was formed by Citrobacter sp., of experimental prawns and $K$. oxytoca of control prawns with bootstrap value of 64. In other way Citrobacter, $E$. coli and Klebsiella of both control and experimental prawns formed a separate cluster at top of the tree. Therefore, species with same genus aligned phylogenetically very close (Figure-13).

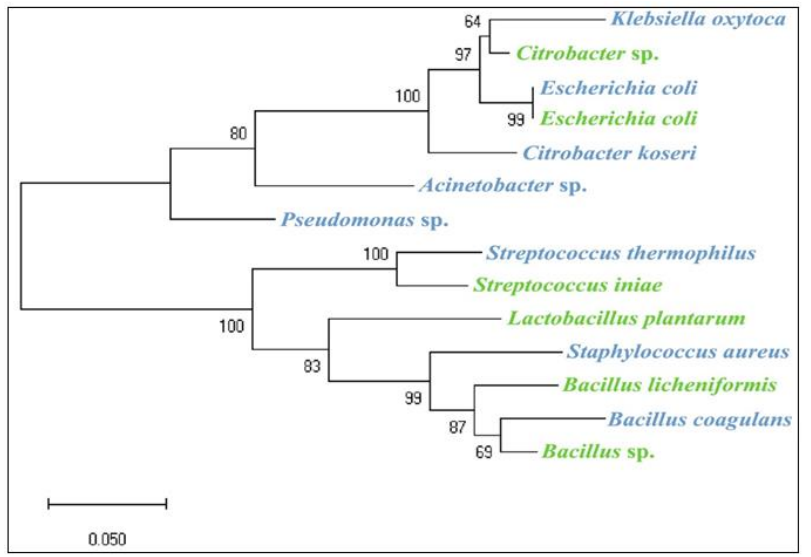

Fig-13: 16S r-RNA based phylogenetic tree topology of bacterial species identified in the gut of $M$. rosenbergii PL fed with control diet and $B$. licheniformis incorporated diet 
Microbial identification in animal husbandry and agriculture is meaningful only when microbiota can be classified to the level of genus or species. The classification of $35-40 \%$ of the reads to a genus or species is considered as a successful result, considering that only a small fraction of all $16 \mathrm{~S}$ gene sequences belonging to uncultivable bacteria are registered in databases [52, 53]. Similarly, the metagenomic analyses using $16 \mathrm{~S}$ r-DNA genes against LactoBacil ${ }^{\circledR}{ }_{\text {plus }}$ and ViBact* ${ }^{*}$ supplemented diets fed $M$. rosenbergii, the colonies established were unknown Proteobacteria of 1355 bp and 1760 bp respectively and have been reported to match and confirmed with genus Ralstonia and Comamonas respectively $[54,55,20,21]$. In the present study, the identified bacterial species using 16S r-RNA sequences showed 99-100\% similarities with the database available with GenBank. Therefore, 16S r-RNA sequence analyses were accurate here.

\section{CONCLUSION}

The bacterial diversity identified using $16 \mathrm{~S} \mathrm{r}$ RNA revealed presence of eight dominant bacteria in the control prawn gut. They were Pseudomonas sp., Klebsiella oxytoca, E. coli, Bacillus coagulans, Streptococcus thermophilus, Staphylococcus aureus, Citrobacter koseri and Acinetobacter sp. In the case of experimental prawn gut, the presence of six dominant bacteria, such as Bacillus sp., Bacillus licheniformis, Lactobacillus plantarum, E. coli, Streptococcus iniae and Citrobacter sp., were identified. This indicated the fact that the pathogenic bacteria Pseudomonas sp., Klebsiella sp., Staphylococcus sp., and Acinetobacter sp., were competitively been excluded by the establishment of $B$. licheniformis colony. Therefore, adhesion and colonization of the probiotic bacterium, $B$. licheniformis in the gut of $M$. rosenbergii has accurately been identified using16S r-RNA gene sequencing.

\section{ACKNOWLEDGEMENT}

The first author would like to thank the Department of Zoology, Bharathiar University, Coimbatore, for providing the required laboratory facilities.

\section{CONFLICT OF INTEREST}

The authors have no conflict of interest.

\section{REFERENCES}

1. Sudha, A., Bhavan, P. S., Manjula, T., Kalpana, R., \& Karthik, M. (2019). Bacillus licheniformis as a probiotic bacterium for culture of the prawn Macrobrachium rosenbergii. Research Journal of Life Sciences, Bioinformatics, Pharmaceutical and Chemical Sciences, 5(4), 44-61.

2. FAO. (2010). The state of world fisheries and aquaculture 2010. Food and Agriculture Organization FAO, Rome, 18-25.

3. Ranjeet, K., \& Kurup, B. M. (2002). Management strategies associating batch-graded and size- graded post larvae can reduce heterogeneous individual growth in Macrobrachium rosenbergii (de Man). Aquaculture Research, 33(15), 12211231.

4. New, M. B. (2005). Freshwater prawn farming: global status, recent research and a glance at the future. Aquaculture Research, 36, 210-230.

5. Wang, Y. C., Lo, C. H., Chang, P. S., \& Kou, G. H. (1998). Experimental infection of white spot baculovirus insome cultured and wild decapods in Taiwan. Aquaculture, 164, 221-231.

6. Tang, Y., Tao, P., Tan, J., Mu, H., Peng, L., Yang, D., Tong, S., \& Chen, L. (2014). Identification of bacterial community composition in freshwater aquaculture system farming of Litopenaeus vannamei reveals distinct temperature-driven patterns. International Journal of Molecular Sciences, 15(8), 13663-13680.

7. Hou, D., Zeng, S., Liu, J., Yan, M., Weng, S., He, J., \& Huang, Z. (2016). Characterization of prokaryotic and eukaryotic microbial community in pacific white shrimp ponds. Journal of Aquaculture Research and Development, 7(12), 463-472.

8. Zhang, D., Wang, F., Dong, S., \& Lu, Y. (2016). De novo assembly and transcriptome analysis of osmoregulation in Litopenaeus vannamei under three cultivated conditions with different salinities. Gene, 578(2), 185-193.

9. Chen, W. Y., Ng, T. H., Wu, J. H., Chen, J. W., Wang, H. C. (2017). Microbiome dynamics in a shrimp grow-out pond with possible outbreak of acute hepatopancreatic necrosis disease. Scientific Reports, 7(1), 9395.

10. Zeng, S., Huang, Z., Hou, D., Liu, J., Weng, S., \& He, J. (2017). Composition, diversity and function of intestinal microbiota in pacific white shrimp (Litopenaeus vannamei) at different culture stages. Peer J, 5, e3986.

11. Rungrassamee, W., Klanchui, A., Maibunkaew, S., Chaiyapechara, S., Jiravanichpaisal, P., \& Karoonuthaisiri, N. (2014). Characterization of intestinal bacteria in wild and domesticated adult black tiger shrimp (Penaeus monodon). PLOS ONE, 9(3), e91853.

12. Yan, Q., Li, J., Yu, Y., Wang, J., He, Z., Van Nostrand, J. D., Kempher, M. L., Wu, L., Wang, Y., Liao, L., Li, X., Wu, S., Ni, J., Wang, C., \& Zhou, J. (2016). Environmental filtering decreases with fish development for the assembly of gut microbiota. Environmental Microbiology, 18(12), 4739-4754.

13. Li, X., Zhou, L., Yu, Y., Ni, J., Xu, W., \& Yan, Q. (2017). Composition of gut microbiota in the gibelcarp (Carassius auratus gibelio) varies with host development. Microbial Ecology, 74(1), 239250.

14. Yao, Z., Zhou, P., Su, B., Su, S., Ye, L., \& Yu, H. (2018). Enhanced isoprene production by 
reconstruction of metabolic balance between strengthened precursor supply and improved isoprene synthase in Saccharomyces cerevisiae. ACS Synthetic Biology, 7(9), 2308-2316.

15. Suzer, C., Kamaci, H.O., Coban, D., Saka, S., Firat, K., \& Ozkara, A. (2007). Digestive enzyme activity of the red porgy (Pagrus pagrus, L.) during larval development under culture conditions. Aquaculture Research, 38, 1778-1785.

16. Hoyoux, C., Zbinden, M., Samadi, S., Gaill, F., \& Compere, P. (2009). Wood-based diet and gut microflora of a galatheid $\mathrm{crab}$ associated with Paciфc deep-sea wood falls. Marine Biology, 156, 2421-2439.

17. Tanu, Deobagkar D. D., Khandeparker, R., Sreepada, R. A., Sanaye, S. V., \& Pawar, H. B. (2012). A study on bacteria associated with the intestinal tract of farmed yellow seahorse, Hippocampus kuda (Bleeker, 1852) characterization and extracellular enzymes. Aquaculture Research, 43(3), 386-394.

18. Zarif, B. R., \& Azin, M. (2014). Identifying probiotics of Macrobrachium rosenbergii's intestine micro flora and their effect in prawn's growth and survival. Advances in Life Sciences, 4(3): 123-130.

19. Bhavani, M., Suneetha, C., Kumaraswamy Naidu, M., \& Reddy M. S. (2015). Monitoring the effect of water and feed probiotics on the growth potentials in the freshwater prawn Macrobrachium rosenbergii. International Journal of Fisheries and Aquaculture Sciences, 5(1), 59-70.

20. Karthik, M., \& Bhavan, P. S., (2018). Supplementation of Lactobacillus brevis for growth promotion of the freshwater prawn Macrobrachium rosenbergii post larvae and identification of gut microflora through $16 \mathrm{~S}$ rDNA. Research Journal of Biotechnology, 13(1), 34-50.

21. Karthik, M., Bhavan, P. S., Seenivasan, V., Asaikkutti, A., Muralisankar, T., \& Mahendran, R. (2018). Dietary supplementation of Lactobacillus fermentum for improving the survival, growth and nutritional profiles of the prawn Macrobrachium rosenbergii, and $16 \mathrm{~S}$ r-DNA based identification of its establishment. Scholar Reports, 3(1), 38-62.

22. Manjula, S., Bhavan, P. S., Karthik, M., Anitha, D., Kalpana, R., \& Manjula, T. (2018). Survival, growth, activities of digestive enzymes, concentrations of basic biochemical constituents and competitive exclusion of pathogenic bacteria in Bacillus coagulans supplemented diet fed Macrobrachium rosenbergii post-larvae. International Journal of Research Studies in Science, Engineering and Technology, 5(12), 922.

23. FAO/WHO. (2002). Guidelines for the evaluation of probiotics in food. Report of a Joint FAO/WHO Working Group on Drafting Guidelines for the Evaluation of Probiotics in Food. Ontario, Canada.
24. Sorokulova, I. B., Pinchuk, I. V., Denayrolles, M., Osipova, I. G., Huang, J. M., Cutting, S., \& Urdaci, M. C. (2008). The safety of two Bacillus probiotic strains for human use. Digestive Diseases and Sciences, 53, 954963.

25. Davis, M. E., Parrott, T., Brown, D. C., de Rodas, B. Z., Johnson, Z.B., Maxwell, C. V., \& Rehberger, T. (2008). Effect of a Bacillus-based direct-fed microbial feed supplement on growth performance and pen cleaning characteristics of growing-finishing pigs. Journal of Animal Science, 86, 1459-1467.

26. Deng, W., Dong, X. F., Tong, J. M., \& Zhang, Q. (2012). The probiotic Bacillus licheniformis ameliorates heat stress-induced impairment of egg production, gut morphology, and intestinal mucosal immunity in laying hens. Poultry Science, 91, 575-582.

27. Yun, H. S., Heo, J. H., Son, S. J., Park, M. R., Oh, S., Song, M. H., \& Kim, Y. (2014). Bacillus licheniformis isolated from Korean traditional food sources enhances the resistance of Caenorhabditis elegans to infection by Staphylococcus aureus. Journal of Microbiology and Biotechnology, 24(8), 1105-1108.

28. De Bore, A.S., Priest, F., \& Diderichsen, B. (1994). On the industrial use of Bacillus licheniformis: A review. Applied Microbiology and Biotechnology, 40(5), 595-598.

29. Pasnik, D. J., Evans, J. J., \& Klesius, P. H. (2008). Bacillus licheniformis isolated during a fish kill is non-pathogenic. Fisheries Science, 74(6), 13511353.

30. Alexopoulos, C., Georgoulakis, I., Tzivara, A., Kritas, S., Siochu, A., \& Kyriakis, S. (2004). Field evaluation of the efficacy of a probiotic containing Bacillus licheniformis and Bacillus subtilis spores, on the health status and performance of sows and their litters. Journal of Physiology and Animal Nutrition, 88(1), 381-392.

31. Kritas, S., Alexopoulos, C., \& Kyriakis, S. (2006). The effect of an EU-registered probiotic on the health status and performance of sows and their litters. In: $3^{\circ}$ Congresso Latinoamericano de Suinocultura, 737-740.

32. Li, K., Zheng, T., Tian, Y., Xi, F., Yuan, J., Zhang, G., \& Hong, H. (2007). Beneficial effects of Bacillus licheniformis on the intestinal microflora and immunity of the white shrimp, Litopenaeus vannamei. Biotechnology letters, 29(4):525-30.

33. Zhang, Q., Tan, B., Mai, K., Zhang, W., Ma, H., Ai, Q., Wang, X., \& Liufu, Z. (2011). Dietary administration of Bacillus (B. licheniformis and B. subtilis) and isomaltooligosaccharide influences the intestinal microflora, immunological parameters and resistance against Vibrio alginolyticus in shrimp, Penaeus japonicus 
(Decapoda: Penaeidae). Aquaculture Research, 42(7), 943-952.

34. Ash, C., Farrow, J. A. E., Dorsch, M., Stackebrandt, E., \& Collins, M. D. (1991). Comparative analysis of Bacillus anthracis, Bacillus cereus, and related species on the basis of reverse transcriptase sequencing of $16 \mathrm{~S}$ rRNA. International Journal of Systematic Bacteriology, 41, 343-346.

35. Nakamura, L. K. (1998). Bacillus pseudomycoides sp. nov. International Journal of Systematic Bacteriology, 48, 1031-1034.

36. Ley, R. E., Backhed, F., Turnbaugh, P., Lozupone, C. A., Knight, R. D., \& Gordon, J. I. (2005). Obesity alters gut microbial ecology. Proceedings of the National Academy of Sciences, 102, 1107011075.

37. Carattoli, A., Bertini, A., Villa, L., Falbo, V., Hopkins, K. L., \& Threlfall, E. J. (2005). Identification of plasmids by PCR-based replicon typing. Journal of Microbiological Methods, 63, 219-228.

38. Joung, K. B., \& Cote, J. C. (2002). Evaluation of ribosomal RNA gene restriction patterns for the classification of Bacillus species and related genera. Journal of Applied Microbiology, 92, 97108.

39. Cox, M. J., Cookson, W. O., \& Moffatt, M. F. (2013). Sequencing the human microbiome in health and disease. Human Molecular Genetics, 22(1), R88-R94.

40. Fox, G. E., Wisotzkey, J. D., \& Jurtshuk, P. (1992). How close is close: 16S rRNA sequence identity may not be sufficient to guarantee species identity. International Journal of Systematic Bacteriology, 42, 166-170.

41. Christensen, H., Nordentoft, S., \& Olsen, J. E. (1998). Phylogenetic relationships of Salmonella based on rRNA sequences. International Journal of Systematic Bacteriology, 48, 605-610.

42. Xu, D., \& Cote, J. C. (2003). Phylogenetic relationships between Bacillus species and related genera inferred from comparison of $3^{\prime}$ end $16 \mathrm{~S}$ rDNA and $5^{\prime}$ end $16 \mathrm{~S}-23 \mathrm{~S}$ ITS nucleotide sequences. International Journal of Systematic and Evolutionary Microbiology, 53(3), 695-704.

43. Stackebrandt, E., \& Swiderski, J. (2002). From phylogeny to systematics: the dissection of the genus Bacillus. In Applications and Systematics of Bacillus and Relatives. Edited by R. Berkeley, M. Heyndrickx, N. A. Logan and P. De Vos. Oxford: Blackwell Publishing, 8-22.

44. Goto, K., Omura, T., Hara, Y., \& Sadaie, Y. (2000). Application of the partial 16S rDNA sequence as an index for rapid identification of species in the genus Bacillus. Journal of General and Applied Microbiology, 46(1), 1-8.
45. De Clerck, E., Van Mol, K., Jannes, G., Rossau, R., \& De Vos, P. (2004). Design of a 5' exonuclease-based real-time PCR assay for simultaneous detection of Bacillus licheniformis, members of the 'B. cereus group' and B. fumarioli in gelatine. Letters in Applied Microbiology, 39(1), 109-15.

46. Stackebrandt, E., \& Goebel, B. M. (1994). Taxonomic note: a place for DNA-DNA reassociation and 16S rRNA sequence analysis in the present species definition in bacteriology. International Journal of Systematic Bacteriology, 44, 846-849.

47. Sambrook, J., Fritschi, E. F., \& Maniatis, T. (1989). Molecular cloning: A laboratory manual. New York: Cold Spring Harbor Laboratory Press.

48. Muse, S. V., \& Gaut, B. S. (1994). A likelihood approach for comparing synonymous and nonsynonymous nucleotide substitution rates, with application to the chloroplast genome. Molecular Biology and Evolution, 11(5), 715-724.

49. Felsenstein, J. (1981). Evolutionary trees from DNA sequences: A maximum likelihood approach. Journal of Molecular Evolution, 17(6), 368-376.

50. Xia, X., Xie, Z., Salemi, M., Chen, L., \& Wang, Y. (2003). An index of substitution saturation and its application. Molecular Phylogenetics and Evolution, 26(1), 1-7.

51. Xia, X., \& Lemey, P. (2009). Assessing substitution saturation with DAMBE. Philippe Lemey, Marco Salemi and AnneMiekeVandamme. USA: Cambridge University.

52. Petrosino, J., Highlander, S., Luna, R., Gibbs, R., \& Versalovic, J. (2009). Metagenomicpyrosequencing and microbial identification. Clinical Chemistry, 55, 856-66.

53. Martinez-Porchas, M., \& Vargas-Albores, F. (2017) Microbial metagenomics in aquaculture: a potential tool for a deeper insight into the activity. Reviews in Aquaculture, 9, 1-9.

54. Jayanthi, L., Bhavan, P. S., Srinivasan, V., Muralisankar, T., \& Manickam, N. (2015). Probiotics product (LactoBacil ${ }^{\circledR}$ plus on improvement of survival, growth, digestive enzymes activity, nutritional status and gut microflora of the prawn Macrobrachium rosenbergii. International Journal of Current Research, 7, 11440-11453.

55. Jayanthi, L., Bhavan, P.S., Srinivasan, V., Muralisankar, T., \& Manickam, N. (2015). Dietary supplementation of probiotics product (ViBact*) on the survival, growth, biochemical constituents and gut microflora of the giant freshwater prawn Macrobrachium rosenbergii post-larvae. Asian Journal of Biomedical and Pharmaceutical Sciences, 2, 67-88. 